\title{
The Training of Teacher of Portuguese as a Host Language
}

\author{
Agenor Francisco de Carvalho \\ Universidade de Aveiro - Aveiro, Portugal
}

Keywords: Host language, Mother tongue, Foreign language, Teachers' training, Interculturality.

\begin{abstract}
Because of the Venezuelan crisis worsening, the Brazilian educational system has been affected, due to the significant increasing of Venezuelan refugee's enrollments. This study is framed in a conceptual axis of the teachers service formation (TSF) in Portuguese as Host Language (PHL). It intends to answer the question: Which contributions the intercultural approach may offer to the TSF or the PHL? The achieved results tell us that it is possible to add to the establishment of linguistic-didactic politics, focused in interculturality while teaching PHL, in the range of TSF. It was adopted as a methodological procedure of systematic literature review, the meta-synthesis. It was observed that it is possible to add to the establishment of linguistic-didactic politics, as long as the interdisciplinarity focuses on the teaching of PHL, in teacher service training.
\end{abstract}

\section{Introduction}

The contemporaneity has been characterized by the abrupt change of all sectors. This work starts from the need to find answers and meaning for the following questions [Q] and objectives [O]: [Q1] What contributions can the focus on interculturality (FI) offer to TSF of Portuguese as a host language (PHL)? [O1]: Reflect on the FI in TSF of PHL. [Q2]: What are the weaknesses (WF) and potentialities (PF) factors that FI can offer to TSF of PHL? [O2] To Identify the WF and PF that FI can offer in the TSF of PHL.

\section{Methodologic Literature Review Process}

To perform corpus analyzes research some criteria was established: i) Period: 2009 to 2019; ii) Distinguished data repository, published by scientific journals and peer reviewed; iii) Languages: at least three different languages (English, Spanish and Portuguese) iv) At least four different geographic backgrounds; v) The methodological description of the work needs to be evident. The research was made using the Booleans logical operators AND, OR and NOT, with string and its English and Spanish variations, in addition to a refined research of the correlated terms. Main Terms: 1) Language - Related Terms: Foreign ; Maternal; Host; Second. 2) Teacher training Related Terms: Immigrant/refugee; Comunicative Competence; Intercultur*

The selection was organized in 4 steps. When adjusting to the research terms, it was adopted the ex/inclusion criteria, and 17 registers were found. When examining the documents it was considered the empiric studies and literature review, as well as those that were linked, one way or another, to the idea of the main terms: Language / Teacher Training and were in specialized 
educational journals. It was limited to 10 studies that were made to answer the initial matter of the research and also when the appropriate uses of the methodology to reach the proposed goals took place with greater clarity. The analysis corpus and the encodings are typified as follows:

A1 - From Performance to linguistic competence; A2 - Host language, language of integration; A3 - Second/Foreign Language Lexical Competence: Its Dimensions and Ways of Measuring It; A4 - Developing intercultural communicative competence across the Americas; A5 - Portuguese language as instrument of reception in Lomba do Pinheiro: reports of pedagogical practices; A6 Oral Communicative Competence of Primary School Students; A7 - Immigration, refuge and language policy in Brazil: reflections on plurilingual school and teacher training based on an educational practice with haitian students; A8 - Building Teacher Interculturality Student Partnerships in University Classrooms; A9 - Portuguese as a Welcoming Language for forcibly displaced immigrants in Brazil: some principles for teaching in light of Interculturality; A10 Haitian student in Chile: approaches to the processes of linguistic integration in the classroom.

\section{Data Analysis Discussions}

After deciding which studies could build the corpus, it was made the reading, analysis and interpretation of them, and, concomitantly, the forms were fulfilled [1,2,3]. With those forms it was possible to perform the fulfillment of the Matrix Concept forms [2], in which an overlap of utilized terms in those papers can be seen and allow the typification of the classes. So that we could ensure the quality of the analysis corpus were used in an appropriate way [3] and the results are presented in table 1.

Table 1. Quality Assessment Parameters

\begin{tabular}{l|l|l|l|l|l|l|l|l|l|l} 
Quality Assessment Parameters & A1 & A2 & A3 & A4 & A5 & A6 & A7 & A8 & A9 & A10 \\
\hline Empirical study & no & no & no & yes & yes & yes & yes & yes & yes & yes \\
\hline Clear definition of study type & yes & yes & yes & yes & yes & yes & yes & yes & yes & yes \\
\hline Qualitative paradigm & yes & yes & yes & yes & yes & yes & yes & yes & yes & yes \\
\hline Quantitative Paradigm & no & no & no & yes & no & yes & yes & yes & yes & no \\
\hline Mixed Paradigm & no & no & not & yes & no & yes & yes & yes & yes & no \\
\hline Use of data analysis software & no & no & no & yes & no & yes & yes & yes & yes & no \\
\hline Definition of research instruments & yes & yes & yes & yes & yes & yes & yes & yes & yes & yes \\
\hline Clear indication of objectives & yes & yes & yes & yes & yes & yes & yes & yes & yes & yes \\
\hline Appropriate use of methodology to objectives & yes & yes & yes & yes & yes & yes & yes & yes & yes & yes \\
\hline Study relevance & yes & yes & yes & yes & yes & yes & yes & yes & yes & yes \\
\hline Clarity in participants and methodology used & yes & yes & yes & yes & yes & yes & yes & yes & yes & yes \\
\hline Grounded and credible results & yes & yes & yes & yes & yes & yes & yes & yes & yes & yes
\end{tabular}

It was observed that all the papers indicate the methodology used in the work, as it was evident the type of study made, the research tolls were explained, the research paradigms were presented (qualitative). The studies combine the use of lots of specific techniques from research of interpretative nature such as: data gathering search for document, interview inquiries, survey forms, investigators journals, observations etc. At the table 2 [1] the categories and the markers indicators that were unveiled when the corpus was analyzed by one the softwares WebQDA were presented with encoding, description indicators and data and Mendeley triangulation- with the establishment of the evidences and emphasis. 
Table 2. Concept Matrix [1]

\begin{tabular}{|c|c|c|c|c|c|c|c|c|c|c|}
\hline \multirow[t]{2}{*}{ Categories } & \multicolumn{10}{|c|}{ Codes } \\
\hline & A1 & A2 & A3 & A4 & A5 & $\mathrm{A} 6$ & A7 & A8 & A9 & A10 \\
\hline Communicative competence [C] & $\mathrm{X}$ & $\mathrm{X}$ & $\mathrm{X}$ & $\mathrm{X}$ & & $\mathrm{X}$ & $\mathrm{X}$ & $\mathrm{X}$ & $\mathrm{X}$ & $\mathrm{X}$ \\
\hline Intercultural Approach [I] & $\mathrm{X}$ & & $\mathrm{X}$ & $\mathrm{X}$ & $\mathrm{X}$ & $\mathrm{X}$ & & $\mathrm{X}$ & $\mathrm{X}$ & $\mathrm{X}$ \\
\hline Teacher Education [T] & $\mathrm{X}$ & & $\mathrm{X}$ & $\mathrm{X}$ & $\mathrm{X}$ & $\mathrm{X}$ & $\mathrm{X}$ & $\mathrm{X}$ & $\mathrm{X}$ & $\mathrm{X}$ \\
\hline Host Language $[\mathrm{H}]$ & & $\mathrm{X}$ & & & $\mathrm{X}$ & & $\mathrm{X}$ & & $\mathrm{X}$ & $\mathrm{X}$ \\
\hline
\end{tabular}

The category Communicative Competence [C] has emerged supported by the Competence indicators: Lexical [C1], Linguistic [C2], of representation [C3], Oral [C4], Performance [C5]. Only the A5 paper drives away from this concept. These indicators emerge in response to the first object [O1]: the concepts that indicate the possibility of the introduction of the working practices made, and that by any chance may direct to the interdisciplinarity approach to be added to TSF of PHL. The category Intercultural Approach [I], emerges as a result of the indicators: Interculturality [I1], Critical Multiculturalism [I2], Inclusive Intercultural Education [I3], Interaction between Teachers and Students [I4], Linguistic integration [I5]. The papers A2 and A7, drive away from this concept. As for the category Teacher Training [F], the following indicators emerge - Critical Pedagogy [F1], Training Weaknesses [F2], Educational Material [F3], Contribution in the Learning Environment [F4]. These categories are parallel to the categories [C], [I] and [L]. The category Host Language [L] reveals the indicators - Mother Language [L1], Foreign Language [L2], Intercultural Approach in PHL Teaching [L3], Language Teaching [L4], and Language Learning [L5].

The next scales will present some text parts, whose samples represent indicator evidence of each categories.

Table 3. Evidence of Indicators of the Communicative Competence Category [C].

\section{C* Cod Evidence}

C1 “(...) proposed a three-dimensional model of lexical competence: (I) partial-to-precise knowledge, (ii) depth of knowledge, and (iii) receptive-to-productive dimension..” [4] “(...) the basic competence in linguistic communication involves a set of knowledge, skills and

C2 attitudes that are interrelated and rely on the communicative act. The knowledge is absolutely necessary for the reflection on the functioning of the language and its procedure of use.” [8]

[C] C3 "(...) communicative competence is based on the use of the language as a tool of communication, both oral and written, of representation, of interpretation and of reality comprehension...” [8]

C4 "(...) to be able to acquire the oral competence would be necessary a continued practice of the oral expression, from the infancy up to the conclusion of the studies, adapted to the age of the pupils." [5]

C5 "Performance is not always the exact match of competence, since competence is often determined by extra-linguistic factors that interact with competence.” [3]

*category

It is possible, in a critical way, to identify in the written fragments of the text the evidences of the indicators linked to the development of the general (C3, C5) and particular (C1, C2, C4) communicative expertise. Depending on the context presented, the term competence may be related to a number of meanings. The concept, since it is inserted in the field of semantics, presents dependency challenges with other similar concepts. The concepts of skills, ability and action are commonly used as synonym for competence.

The transcribed excerpts from the papers show that the indicators from the category [F] depart from such approach in order to reach the objective. The refugee and/or immigrant students belong to a public with different characteristics from the local students, reason why offering a welcoming learning space has been a great challenge in contemporary education. Forcibly displaced from their origins, in addition to the psychological factors that this action represents, they are added an 
invisible boundary, which becomes impassable, if they do not overcome it - the boundary of the linguistic differences. Therefore, it was verified, in all the articles used to build the corpus of this research, that the intercultural approach is a strategy to work with the teaching of PHL to immigrants and/or refugees.

Table 4. Evidence of Indicators from the Intercultural Approach Category [I].

\begin{tabular}{|c|c|c|}
\hline C & Cod & \\
\hline \multirow{5}{*}{ [I] } & I1 & $\begin{array}{l}\text { "(..) from to the advances in the knowledge of the linguistic interculturality in the classroom and its } \\
\text { challenges in different cultural contexts to Chile (...), we can approach the phenomenon with greater } \\
\text { solidity.” [12] }\end{array}$ \\
\hline & I2 & $\begin{array}{l}\text { "In short, Critical Multiculturalism or Interculturality, as (...) prefers, recognizes "the dynamic, } \\
\text { hybrid, non-consensual, and nonhierarchical character of cultures" and "brings to the center of the } \\
\text { debate the differences of forces between different cultural groups." [11] }\end{array}$ \\
\hline & I3 & $\begin{array}{l}\text { "(...) in practice, it is applying the clearly differentiated approaches: } 1) \text { inclusive, working in a } \\
\text { cooperative manner with immigrant students in the ordinary class and 2) segregationist, in which the } \\
\text { alumni care immigrant takes place in the ordinary classroom." [12] }\end{array}$ \\
\hline & I4 & $\begin{array}{l}\text { "(...) the processes of cultural integration and linguistic integration. The first one has as a premise the } \\
\text { interaction and acceptance among the resident social actors and the newly recruited" [12] }\end{array}$ \\
\hline & I5 & $\begin{array}{l}\text { "Clearly the school observed in the reflection of a public policy that has interest in linguistic and } \\
\text { cultural integration." [12] }\end{array}$ \\
\hline
\end{tabular}

Table 5. Evidence of the Indicators of the Teacher Training Category [F].

C Cod Evidence

"These concerns for power, equity, and reciprocity have led educators who employ critical service-

F1 learning to attend to program design that encourages sustained engagement, collaboration, and reflection.” [5]

“ (...) undergraduate curriculum aimed at the training of teachers in all areas (Pedagogy, Letters and

F2 other Bachelor Degrees) should, as an educational PL, offer courses on topics such as "plurilingual

[T] education" and "PHL", aiming at a citizen formation.” [9]

F3 “(...) discusses PHL teaching and learning for Bolivian immigrants in São Paulo. (...) points to the need to create teaching materials specific to the host language.” [9]

"The integration of telecollaboration as a pedagogical tool in language teaching expands the treatment of cultures, which, according to [14], was previously nonexistent or limited to isolated facts and homogenous descriptions." [6]

Although the used fragments talk about some teacher's training matter to use the host language, the article A7 is the one that is closer to this approach.

Table 6. Evidence of Indicators in the Host Language Category

\begin{tabular}{|c|c|c|}
\hline C & Cod & Evidence \\
\hline \multirow{5}{*}{ [H] } & L1 & $\begin{array}{l}\text { "The concept of mother tongue alludes to the language of the first socialization, which generally has the } \\
\text { family as its main transmitter.." [4] }\end{array}$ \\
\hline & $\mathrm{L} 2$ & $\begin{array}{l}\text { "The foreign language is not the language of the first socialization, it is another language with the } \\
\text { worldview of another society." [4] }\end{array}$ \\
\hline & L3 & $\begin{array}{l}\text { "In the literature on PHL related to immigration and refuge, for example, the subject of this paper, we } \\
\text { find terms such as language of immigration, host, integration, which refer to learning purposes as } \\
\text { related to survival needs and social inclusion in the area. immigration country." [9] }\end{array}$ \\
\hline & L4 & $\begin{array}{l}\text { “(...) Thus, I endorse (...) conviction that an emancipatory teaching, from the perspective of } \\
\text { Interculturality, associated with advances in legislation in favor of this population as well as the } \\
\text { surrounding education, could be crucial in this regard.” [11] }\end{array}$ \\
\hline & L5 & “(...) any teaching-learning process aims to meet the learner's needs and motivations.” [11] \\
\hline
\end{tabular}


The host language is addressed in the papers A2, A5, A7, A9 and A10. It was observed the importance of the uses of the language as the first way to welcome the immigrant and/or refugee. The paper A9 supports that the PHL for immigrants that were forced to move to Brazil should be upheld in the intercultural dialog. The paper A5 elucidates that the PHL is taught to immigrants in different textual needs and even in survivorship situations, when urgency shows up, a situation in which a HL raises as a communication link, of inclusion and guarantee of full citizenship [7].

\section{Conclusion}

In the contemporaneity, welcoming immigrants and/or refugees is a true challenge for all the government representatives, even more for the education. Thereby, in the last five years, the compelled motherland immigration has been increased, not only in the Euro Zone or in the United States of America, but in regions were the immigration process was not relevant, like in the South America background. When they get into that country, apart from the personal sufferings, they face the challenge of learning a new language. That is why the training of teachers of Portuguese needs a new perspective. Notably, to drive the training focus to teaching the teachers how to use Portuguese as a host language. The statement that the host language "... it is truly the most inclusive methodology ..." and it's domain is built in the “... most powerful way of social integration, to reach the equality of opportunities and the practice of the full citizenship". [13].

Using these articles, the meta-analysis was made, observing some didactic strategies of teaching welcoming languages in Spain, USA, USA/China, Chile and Brazil. It was seen that the intercultural approach has been proved as an important strategy of welcoming immigrants and/or refugees, because it presents a new perspective of teaching and learning a new language. Also, the training needs to be focused in aspects of the linguistic differences, the multicultural and multilinguistic contexts that may characterize the immigrants and/or the refugees. In addition to these aspects, it is necessary to understand that the teaching and learning environments of one welcoming language exceeds the boundaries of the school environment. It pervades the family environment, the community environment, and all the social relations that the immigrants are inserted.

\section{References}

[1] K. Buijserd, Demand-based learning in higher education from an organizational perspective: An assignment at KPMG (Master's thesis, University of Twente). 2009.

[2] T. Dyba, \& T. Dingsoyr, Empirical studies of agile software development: A systematic review. Information and Software Technology, 50(9-110), 833-859. 2008.

[3] L. G. Xavier, From Performance to Language Competence. Máthesis Journal. No 19 Portuguese Catholic University, Viseu. Department of Letters (2010).

[4] M. J. R. Grosso, Host language, integration language. In Horizons of Applied Linguistics. 9-2. (pp. 61-77) Lisbon. 2010

[5] A. S. Choudhury, Second/Foreign Language Lexical Competence: Its Dimensions and Ways of Measuring It Journal on English Language Teaching, v5 n3 p34-42 Jul-Sep. 2015.

[6] D. C. DiFrancesco, O. Mora \& A. S. Collazos, Developing intercultural communicative competence across the Americas, 2016. 
[7] G. H. Andrighetti, C. B. L. Perna, \& M. M. Porto, Portuguese language as instrument of reception in Lomba do Pinheiro: reports of pedagogical practices. BELT- Brazilian English Language Teaching Journal, 8(2), 191-208. 2017.

[8] I. C Mayo \& E. P. Barrioluengo, Oral Communicative Competence of Primary School Students Journal of Education and Learning; Vol. 6, No. 4; Published by CCSE. 2017.

[9] G. S. Bulla; R. L. Silva; J. C. Lucena, \& L. P. Silva. Immigration, refuge and language policy in Brazil: reflections on plurilingual school and teacher training based on an educational practice with haitian students. In Organon - Institute of Letters of UFRGS Journal, 32(62). 2017

[10] E. Smolcic \& B. Arends, Teacher Interculturality Student Partnerships in University Classrooms. Teacher Education Quarterly, Fall 2017. https://files.eric.ed.gov/fulltext/ EJ1157418.pdf

[11] A. P. A. Lopez, Portuguese as a Welcoming Language for forcibly displaced immigrants in Brazil: some principles for teaching in light of Interculturality Rev. bras. linguist. apl. vol.18 no.2 Belo Horizonte. 2018.

[12] J. L. Campos-Bustos, Haitian student body in Chile: approaches to linguistic integration processes in the classroom. Educación Journal, vol43, n1, University of Costa Rica, Costa Rica. 2019.

[13] M. H. Ançã, The host language in the portuguese education. In Anais do XI CONSIPLE.(pp. 34-44) Salvador. 2016. 